\title{
DESIGN INTERACTIVE QUR'AN LEARNING FOR KINDERGARTEN BASED ON ANDROID
}

\author{
Thabrani $\mathrm{R}^{1}$, Muh. Syahlan Natsir ${ }^{2}$ \\ ${ }^{1}$ Informatics Engineering Study Program STMIK Dipanegara Makassar, Indonesian \\ thabranidp@gmail.com ${ }^{1}$ \\ ${ }^{2}$ Informatics Engineering Study Program STMIK Dipanegara Makassar, Indonesian \\ sahlan@dipanegara.ac.id ${ }^{2}$
}

\begin{abstract}
The Institute for the Development and Development of Al Qur'an Kindergarten (LPPTKA) in Sidrap city is an organization of the Indonesian Youth Mosque Youth Communication Agency (BKPRMI). LPPTKA BKPRMI Sidrap city is an educational institution that seeks to foster and develop the reading, writing, understanding and practicing the Qur'an through TKA / TPA units. As is known, basic religious education for early childhood is very important, where basic religious education special attention to children. The Qur'an Education Park (TPA) has become a forum for debriefing the basics of religion for children such as learning iqro ', prayer, ablution and many more. The learning method used in most TPAs in Sidrap Regency still uses a general learning system such as using prayer books or iqra books so that students easily feel bored, especially when learning is very limited so that the knowledge gained is not maximal if they do not repeat home. By using an Android-based interactive learning application, it will provide a new way of learning and know technology to students so that it can increase the interest and quality of TK/TPA students in Sidrap district.
\end{abstract}

Keywords: Ablution; Android Application; Iqro '; Prayer; TK/TPA.

\section{INTRODUCTION}

The Institute for the Development and Development of the Al Qur'an 'Kindergarten (LPPTKA) of Sidrap city is an organization of the Indonesian Youth Mosque Youth Communication Agency (BKPRMI). LPPTKA BKPRMI Sidrap city is an educational institution that strives to foster and develop the reading, writing, understanding and practicing the Qur'an through TKA/TPA units as well as a vehicle for public service in the Qur'an education and teaching especially for the children in the mosque, mushalla and so on. The purpose of LPPTKA BKPRMI is to realize the Qur'ani generation, the generation of believers who are faithful and devoted to making the Qur'an the main reading and guidance of their lives, having the right to be healthy, intelligent and have dynamic independence and a high sense of social responsibility in the community madani.

Education Park (TK/TPA) is a non-formal type of religious education unit based on the Muslim community that makes the Qur'an as its main material, as well as learning Islamic religious learning materials such as the Koran, prayer procedures, procedures ablution, and guide them to become religious Muslims. The learning method used in most TPAs in Sidrap
Regency still uses a general learning system such as using prayer books or iqra books like other TK/TPA so students are easily bored, especially when learning is very limited. In addition, the learning process runs for approximately 1 hour, starting after the evening prayer and finished before the evening prayer, while the mastery process is not determined because the focus of learning is smooth and fluent in reading the Qur'an. This is done to provide new ways of learning and know technology to students, especially LPPTKA BKPRMI TK/TPA, let alone how to access it using an Android-based smartphone where Android-based smartphone users are smartphones with the most users.

There have been several studies that were previously carried out on Android-based interactive learning applications. In an effort to develop and improve the development of Interactive Learning applications this, literature study is needed (literature review) as one of the application of research methods done, including:

1. Research conducted by Kgs.M.Hendra, et. al with the title "Design of Android-Based Iqra Learning Applications". This system is to help children to recognize hijaiyah letters, pictures the object is accompanied by the name of the object in Arabic and Indonesian, can distinguish the gift and how to pronounce it [1].

2. Research conducted by Parno, et. al with the title "The Design of E-Learning Applications for Complete Prayer Guide based on Android Mobile". This study aims to make it easier for everyone who wants to learn prayer by knowing information about the complete guide to prayer [2] .

3. Research conducted by Ach Fauzan, et. al with the title Development of Android-based Iqra Applications using Google Speech. This system builds an Android-based iqro learning media application and integrates it with Google speech so that applications that are built are more interesting and interactive with their users. Google speech is integrated in the feature feature, the user is asked to answer every question using voice then Google speech functions to convert sound into text [3].

4. Research conducted by Jodi Hendrawan with the title "Design of Mobile Learning Applications for Prayer Guidance" This system is used by utilizing information technology to present information about prayer, ablution 
and adhan for Muslims to be more effective, accessible anywhere , anytime, and the delivery of information becomes more interactive [4].

From several literature review sources and previous studies, researchers saw that the application of interactive learning applications still focused on one activity such as the iqra learning application, prayer and ablution learning applications. As the development of the previous system, the researchers designed an Android-based interactive learning application by combining several activities in one application. With this interactive learning application, the author hopes to be a solution to the problems faced by the existing TK/TPA LPPTKA BKPRMI students in Sidrap district.

\section{METHOD}

\section{A. Types of research}

To perfect the data needed in the framework of preparing this proposal, the authors collect data using two methods, namely:

1. Research library (Library Research), which is data collection by reading books through the study of literature, tutorials and articles from the internet that are scientific in relation to the discussion material.

2. Field Research (Field Research), which is one method that is done by collecting data directly to the object of research, namely by doing direct practice on the Windows operating system that will be used as an object of research.

\section{B. Method of Collecting Data}

In this research activity, the author uses several methods which are used as data collection methods needed:

1. Interview The interview allows the system analyst as an interviewer to collect data face-to-face directly with the interviewee. In this case the author will conduct interviews directly with the community.

2. Observation (Observation) Observation is a direct observation of an activity that is being carried out. Here the author makes direct observations of activities

\section{System Testing Techniques}

According to [5], "Black Box testing is testing the fundamental aspects of the system without regard to the internal logic structure of the software." 5

The author uses the Black box testing method or commonly called logic flow which is one of the software testing methods in detail, because the logic path (software path) of the software will be tested by providing a test case that works on a specific set of conditions or repetitions.

By using the black-box method the author can find errors in the following categories:

1. Functions that are incorrect or incorrect

2. Interface error

3. Errors in data structures or external databases

4. Performance errors

5. Installation and termination errors.
D. Research Tools and Materials Research Tools

TABLE 1

Hardware

\begin{tabular}{|c|c|c|c|}
\hline No & Hardware Names & Unit & Spesification \\
\hline 1. & Azus Notebook & 1 & $\begin{array}{ll}\text { - } & \text { Processor Intel Core i5 } \\
\text { - } & \text { Memory (RAM) } 4 \text { GB } \\
& \text { DDR3 } \\
\text { - } & \text { VGA N NVIDIA } \\
& \text { GEFORCE 720M } \\
\text { - } & \text { Harddisk (HDD) } 500 \\
& \text { GB }\end{array}$ \\
\hline 2. & $\begin{array}{l}\text { Android } \\
\text { Smartphone }\end{array}$ & 1 & $\begin{array}{l}\text { - } \text { Memory (RAM) } 3 \text { GB } \\
\text { - OS Android, } \\
\text { Lollypop }\end{array}$ \\
\hline
\end{tabular}

TABEL 2

Software

\begin{tabular}{l|l|l|l}
\hline No & Software Names & Unit & Spesification \\
\hline 1. & Operation System & 1 & Windows 10 64bit \\
\hline & & & $\begin{array}{l}- \text { Android Studio } \\
-\end{array}$ \\
2. & Support Software & 1 & $\begin{array}{l}\text { Xampp } \\
-\end{array}$ \\
& & & Mysql Database \\
\hline
\end{tabular}

\section{E. Conceptual Design Tool}

In this research activity the author uses tools to analyze and study the existing system and the system to be designed. The tool used is an electronic voting system chart and the Unified Modeling Language (UML).

\section{F. Material Used}

The materials used in this study are as follows:

1. Problems occur in the learning process in TK/TPA

2. Learning materials for TPA / TQA students 3. Books relating to the teaching of TPA / TQA

\section{RESULT AND DISCUSSION}

\section{A. Planning System}

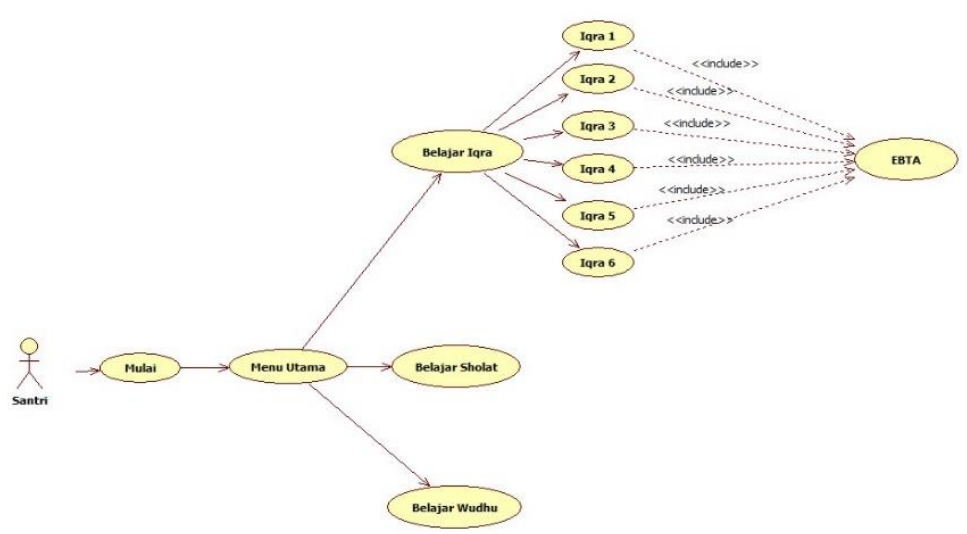

Fig. 1. Use Case Diagram 
Use case diagram serves to describe actions - actions that can be done by an actor (user). Use case describes the functions provided by the system, while actors are individuals or someone who interacts directly with the system. Use Case diagram is designed to describe what the system is doing and what is done by actors who interact with the system so that the user can understand about the system to be created. Fig. 1 which illustrates the Use Case Diagram.

\section{B. Diagram Activity}

Activity Diagram is used to describe the activities that can be carried out by the actor from activities starting until the end of the activity. Activity Diagrams are also used to describe activities that are formed in an operation so that they can also be used for other activities such as use cases and interactions.

The following is figure 2 which illustrates the registration activity diagram carried out by the user.

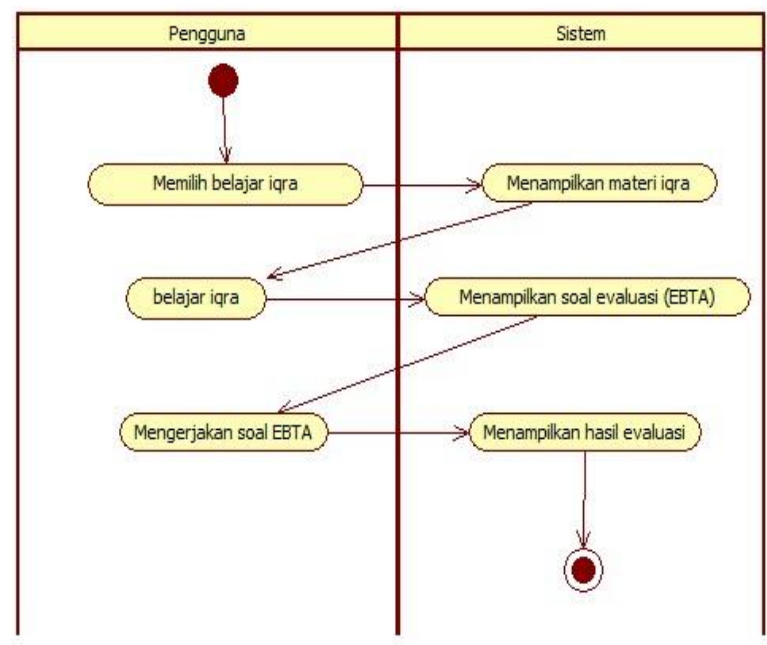

Fig. 2. Page Start Activity Diagram

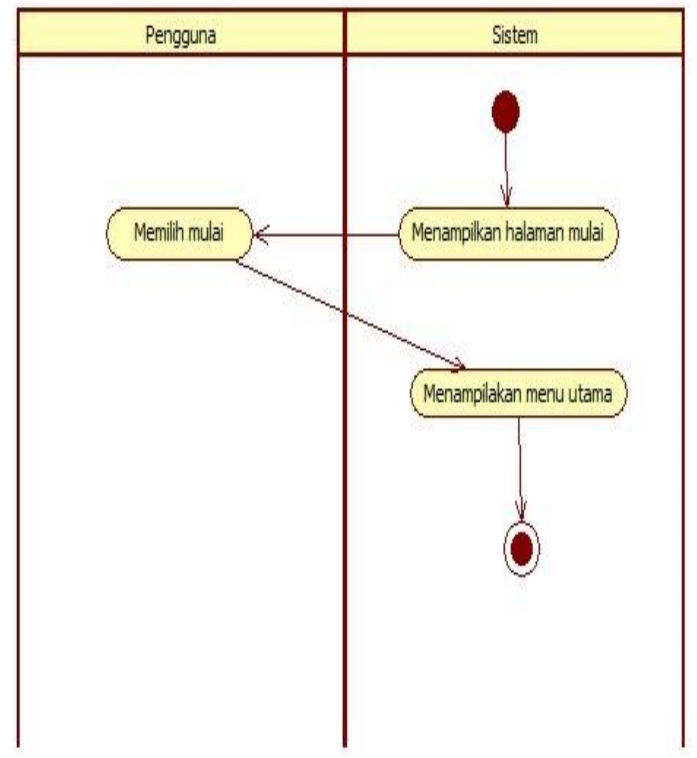

Fig. 3. Activity Diagram Learning Iqra Level

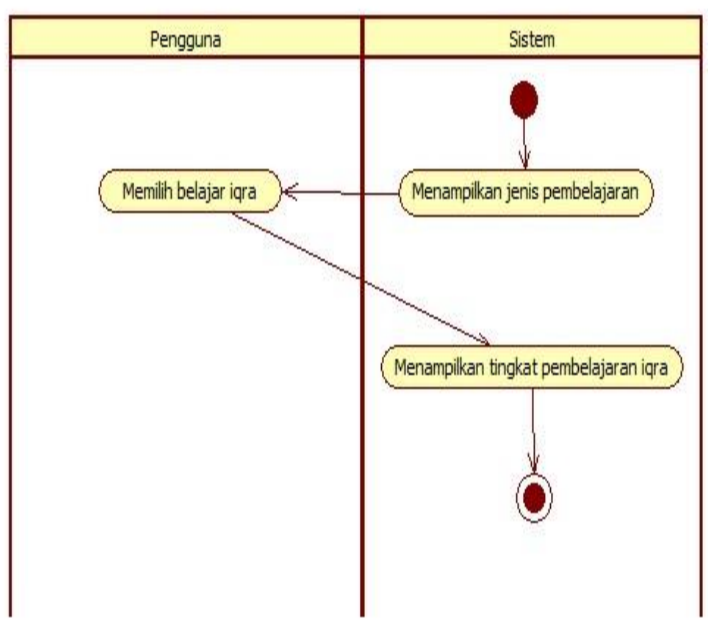

Fig. 4. Activity Diagram Learning Iqra

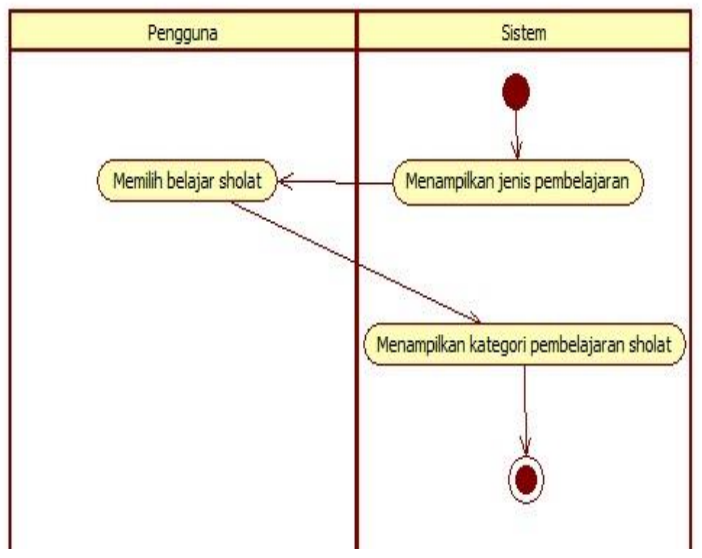

Fig. 5. Activity Diagram Learn Prayer

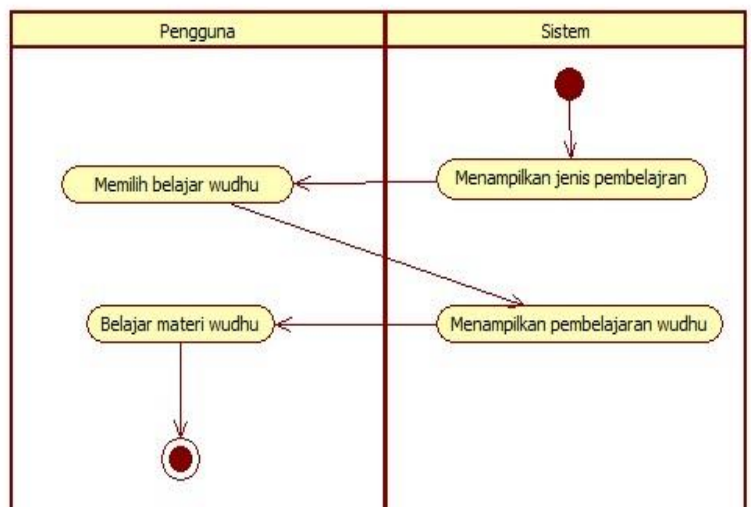

Fig. 6. Activity Diagram Learning ablution

\section{Sequence Diagram}

Sequence diagrams are interactions between objects in a system and communication occurs in the form of messages and time parameters.

Here is figure 7 which illustrates the Main Page Sequence diagram. 


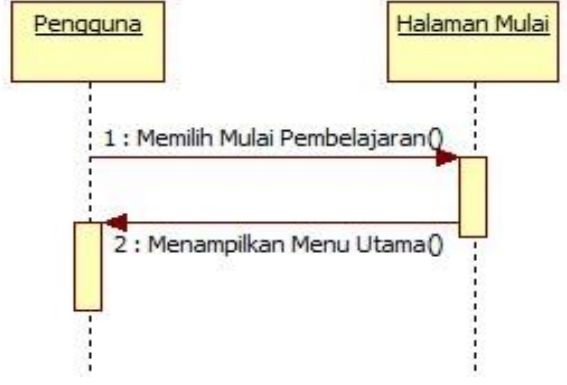

Fig. 7. Main Page Sequence Diagram

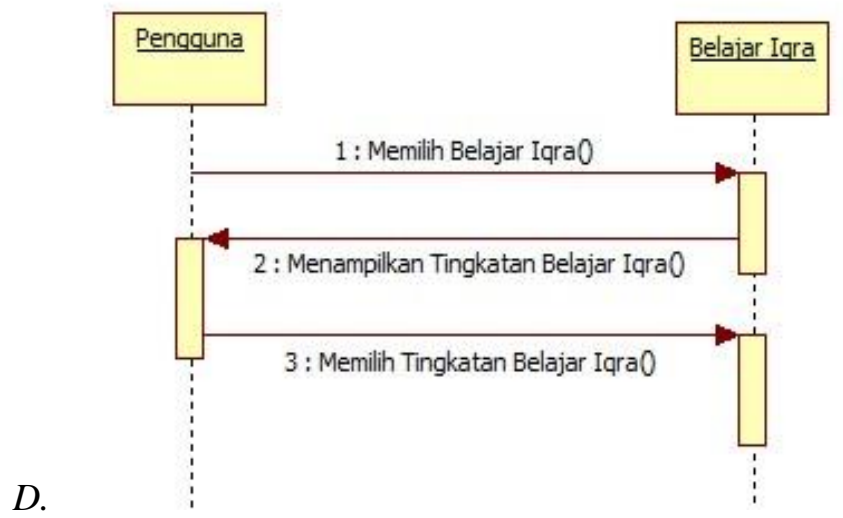

Fig. 8. Sequence Diagram Learn Iqra

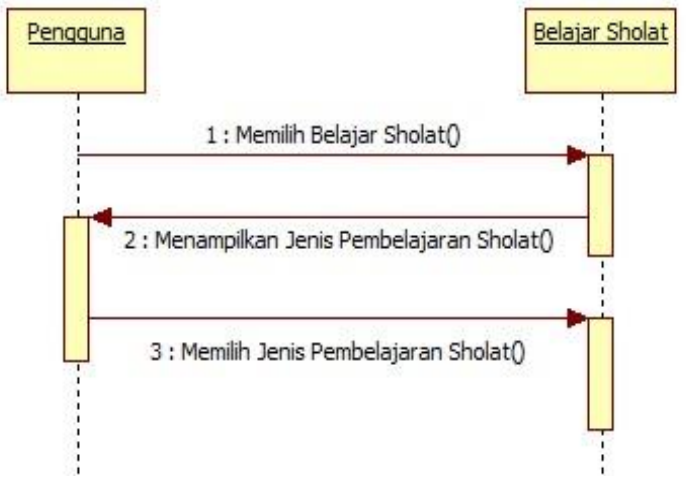

Fig. 9. Sequencey Diagram Learning Pray

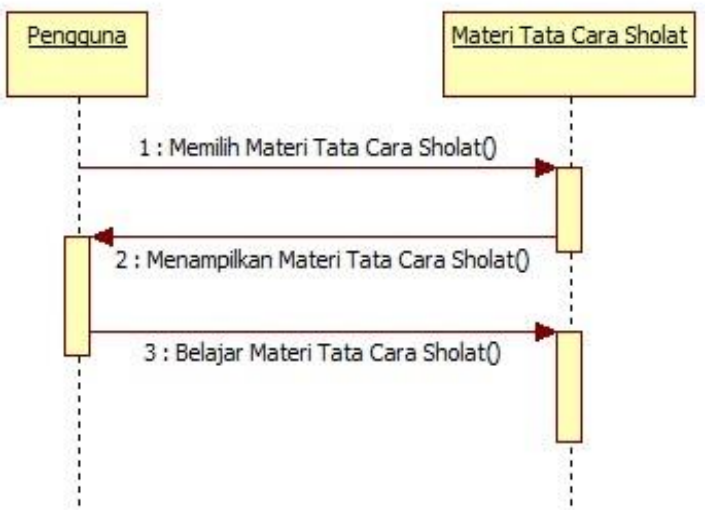

Fig. 10. Sequence Diagram for Prayers

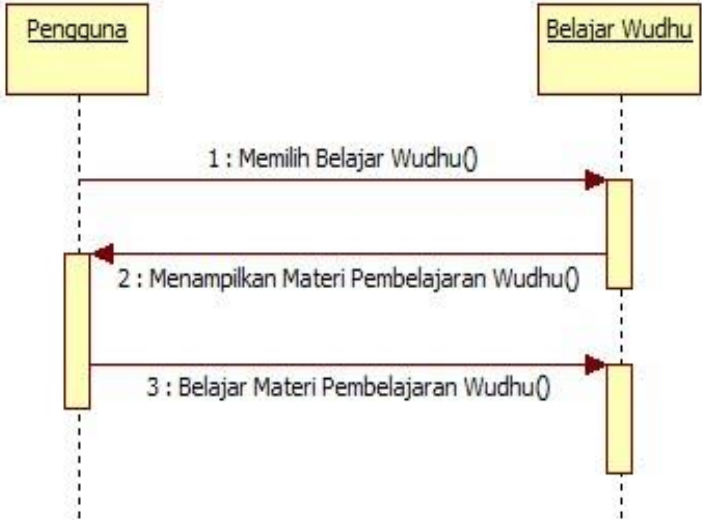

Fig. 11. Learning Ablution Sequence Diagram

\section{E. Class Diagram}

Class diagrams describe the interactions between classes and the attributes inherent in the class.

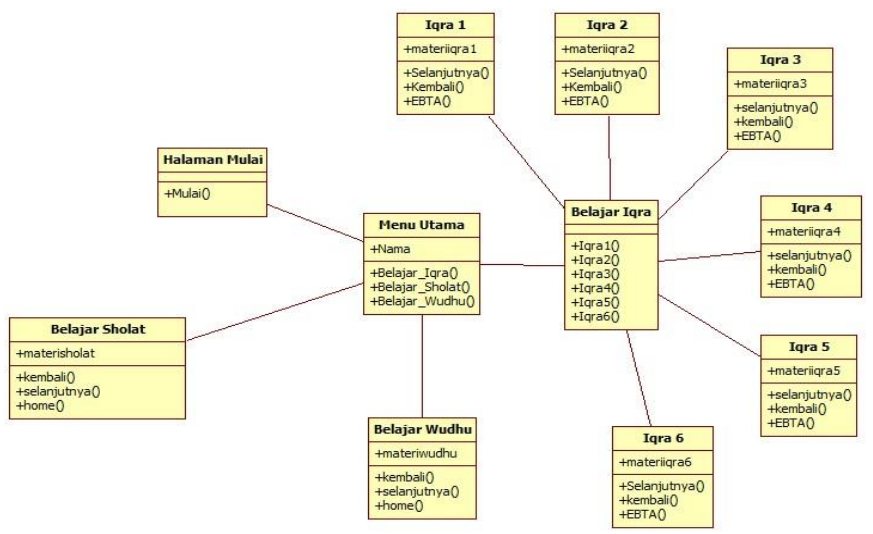

Fig. 12. Class System Diagram

\section{F. Basis Data (Database)}

To facilitate programming in the process of inference mechanism must be carried out by searching techniques and data manipulation. In using SQL-Lite databases, data storage is supported by offline application features, as for the table design we use as in the table below

Here is Table 3 which is a table of EBTA storage planning each iqra

TABLE 3

Questions Design Table

\begin{tabular}{l|l|l|l|l|l|l|l}
\hline soal_id & soal & Pil_a & Pil_b & Pil_c & url_img & jwban & soal_id \\
\hline & & & & & & & \\
\hline
\end{tabular}

\section{G. Aplication View}

In this section, it is explained in detail the appearance of the application and the process that must be carried out in running this application to completion. The following is the application view. 
Main Page Form

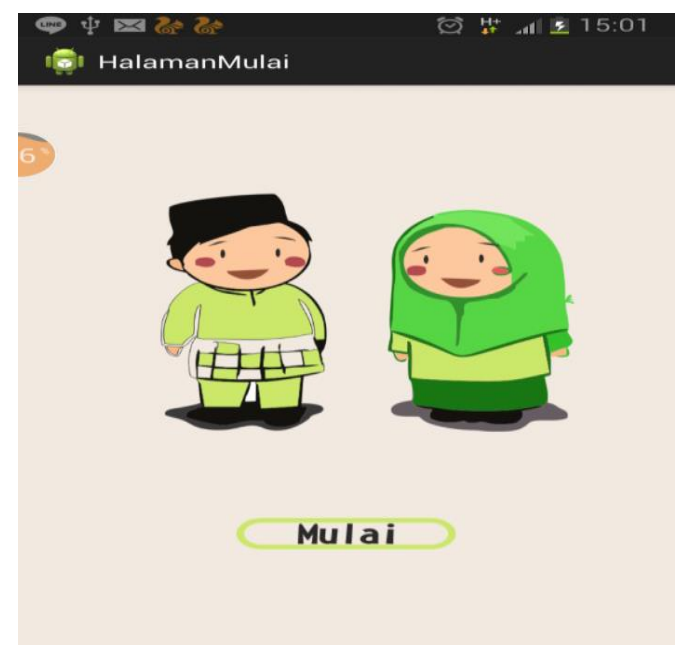

Fig. 13. Form main page

On this main page each student must press the start button, then enter their name.

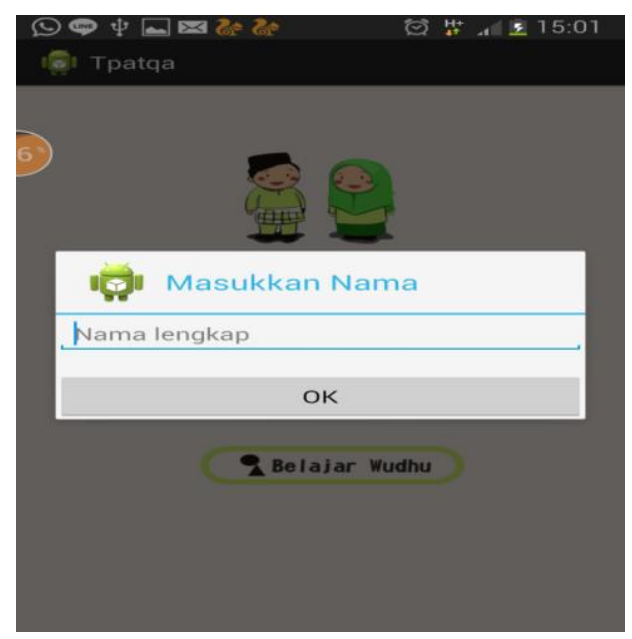

Fig. 13. Form input name

\section{TK/TPA Material Menu Form}
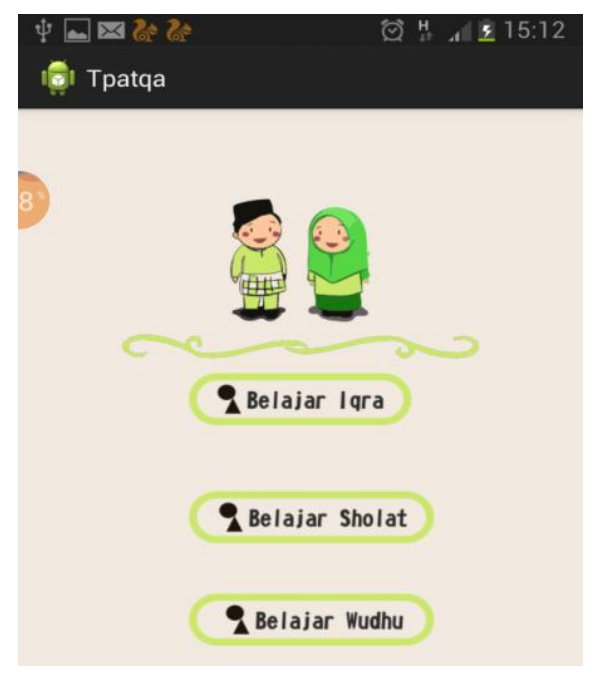

Fig. 14. Material form

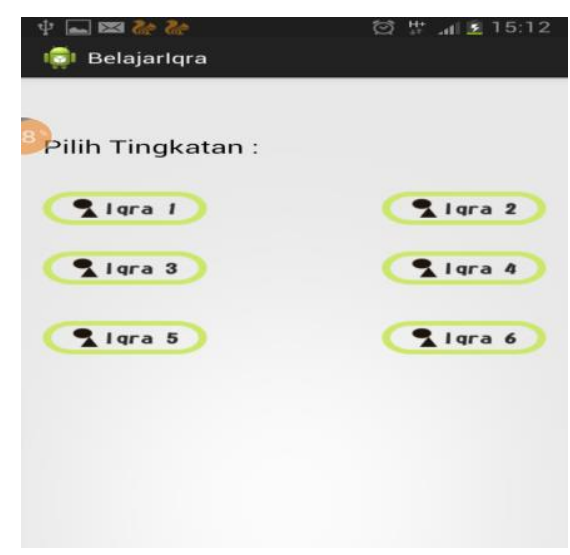

Fig. 15. Form level iqra

Iqra Learning Form

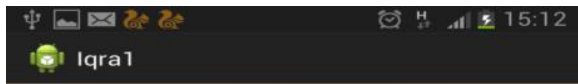

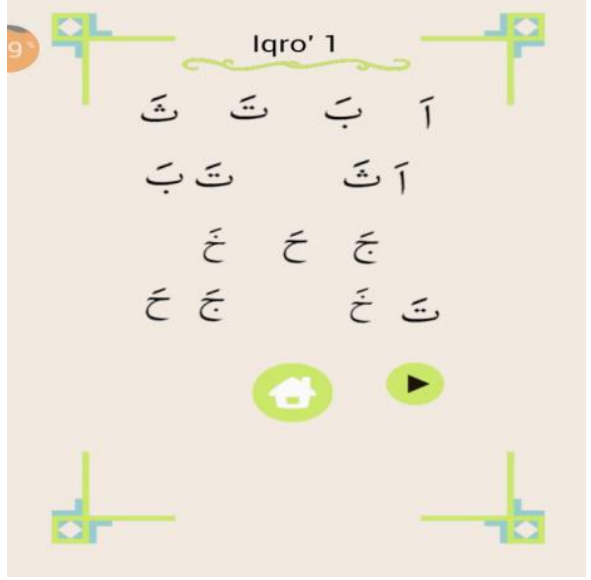

Fig. 16. Iqra learning form

Prayer Learning Form

क्षि BelajarSholat
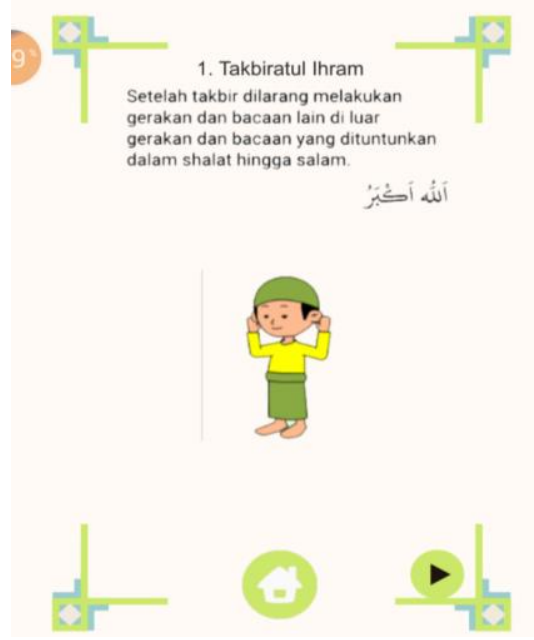

Fig. 17. Prayer learning form 


\section{Ablution Learning Form}

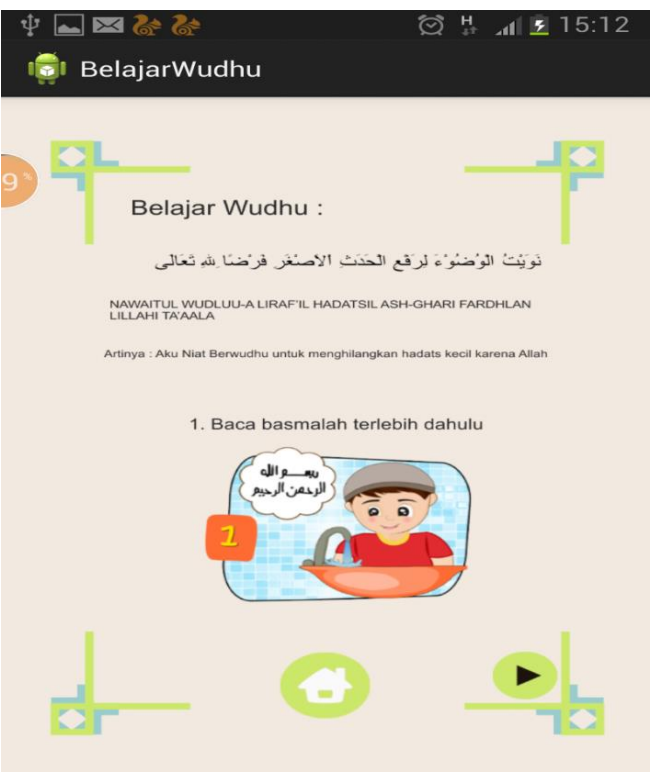

Fig. 18. Ablution learning form

\section{Ebta Form}

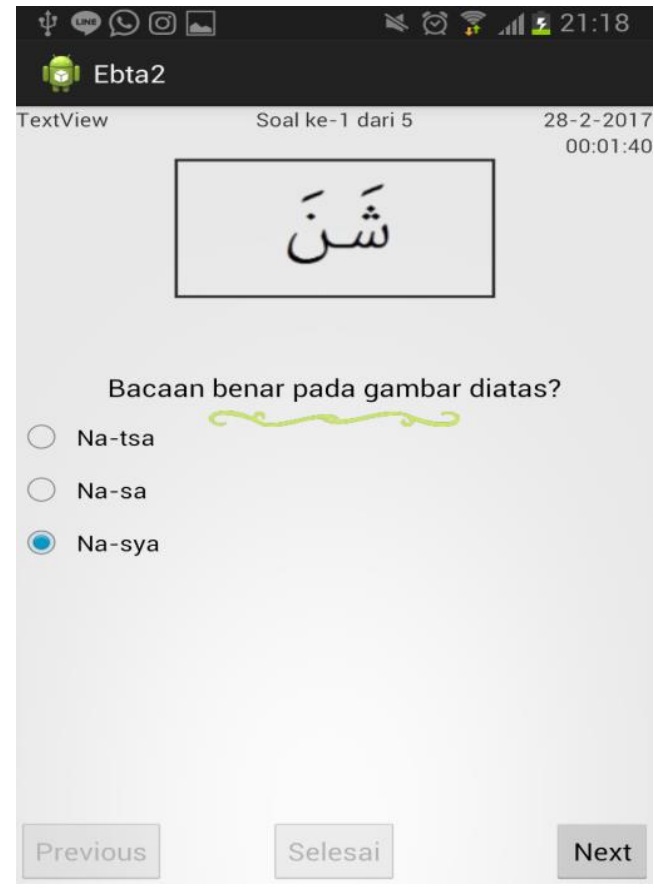

Fig. 19. Ebta Form

\section{CONCLUSION}

Based on he results of the research and discussion that has been described, we can conclude that this application can provide convenience for children in learning Iqra, learning prayer and learning ablution, it is also expected that this application becomes an additional learning media that can be used by children anytime and anywhere.

Whereas for future development it is expected that this system can be developed by adding more learning references so that users understand better. Besides that, more evaluation questions for EBTA are needed to provide more training to application users.

\section{ACKNOWLEDGMENT}

The author would like to thank all parties who have provided input, suggestions and assistance both in terms of completing and implementing this application. So that this research can be presented in the form of a journal

\section{REFERENCES}

[1] A. R. N. A. W. Kgs. M.Hendra, "Design of Android-Based Iqra Learning Applications," 2013.

[2] D. B. D. R. Parno, "Design of E-Learning Applications for Complete Prayer Guidelines Based on Android Mobile," JOURNAL OF SANTIKA, 2013.

[3] I. A. L. F. Ach Fauzan, "Development of Android-based Iqro Applications Using Google Speech," Journal of Information Technology Development and Computer Science, vol. 2, no. 1, 2018.

[4] J. Hendrawan, "Design of Mobile Learning Applications for Prayer Guidance," JURNAL INTECOMS, vol. 1, no. 1, 2018.

[5] R. Pressman, Software Engineering, Yogyakarta: Andi, 2010. 